\title{
VÁLLALATI EGYÜTTMÜKÖDÉSEK A HATÁR MENTÉN MAGYAR SZEMSZÖGBŐL
}

\author{
(Enterprise Co-operation along the Border from Hungarian \\ Point of View)
}

\section{GROSZ ANDRÁS}

\begin{abstract}
Kulcsszavak:
Nyugat-Dunántúl Burgenland hatârmenti együttmüködés vállalkozások gazdaság

A tanulmány célja, hogy bemutassa a határnak a Nyugat-dunántúli régióban müködö vállalkozások mindennapi tevékenységére, müködésre gyakorolt hatását. A határ jelentôs szerepet játszott a Nyugatdunántúli régió, Magyarország egyik legdinamikusabb gazdasági növekedéssel jellemezhetö országrészének elmúlt 15 éves fejlódésében. Különösen fontos volt e szerep a külföldi müködötóke-bejövetel, a nyugati piacokhoz való közelség, valamint a nyugati, föleg osztrák vállalkozói szférára jellemzö minták átvétele terén. A sokáig elszigetelt határ a nyolcvanas évek végén felerôsödó változások eredményeként gyorsan alakult át határ menti térséggé, mely átalakulási folyamat az EU-csatlakozással és az áruk, szolgáltatások, valamint a termelési tényezök jövöben várható teljesen szabad mozgásával várhatóan egy speciális integrált határrégió létrejöttéhez vezet. E határrégió sajátosságainak egyik fontos dinemziója a gazdaság, a határrégióban müködö vállalkozások határon átnyúló tevékenysége, piaci kapcsolatrendszere, együttmüködési lehetöségei, valamint fokozódó versenyhelyzete, illetve általában a határmentiségböl fakadó gazdasági, valamint nem gazdasági elönyök és hátrányok.
\end{abstract}

\section{Elözetes hipotézisek}

A Nyugat-dunántúli régió elmúlt másfél évtizedes dinamikus fejlödésének és viszonylag gyors és sikeres gazdasági szerkezetváltásának egyik kiemelkedő fontosságú háttértényezője a térség földrajzi elhelyezkedéséből és nyugati határmenti-ségéból fakadó lehetőségek kihasználása. Ugyanakkor a határmentiség nem mindig elönyként jelent meg a régió gazdasági életében. A második világháborút követő fordulat, Európa és a világ két politikai és gazdasági rendszerre szakadása eredményeként leeresztett „Vasfüggöny” évtizedekre elvágta a meglévő gazdasági és társadalmi kapcsolatokat a határ túloldalán lévő partnerekkel. Ebben az időszakban a gazdaság fejlödése szempontjából a nyugati határhoz való közelség nemhogy előnyként, hanem kifejezetten hátrányként jelentkezett. A mai Nyugat-dunántúli régió gazdaságára egyértelműen egyfajta periférikusság volt jellemző, különösen a határhoz közvetlen közel fekvő térségekben, ahol a gazdaságfejlesztés szigorú korlátok között mozgott, s a térséget tulajdonképpen nem érintette a szocialista iparosítás. A korlátozott gazdaságfejlesztés, periférikus gazdasági szerep és funkciók, valamint a határ átjárhatatlansága miatt a határon átnyúló együttmúködések száma és intenzitása is rendkívül korlátos volt, mely csak az 1980-as évek elején kezdett enyhülni és kibontakozni. 
A régió gazdasági fejlődésében és a határ menti kapcsolatok újjálesztésében, dinamikus bővülésében meghatározó mérföldkövet jelentett az 1989/90-es rendszerváltás, valamint a „Vasfüggöny” lebontása. A politikai és gazdasági rendszerváltást követően a nyugati orientáció elötérbe kerülése, az Európai Unió és az Észak-Atlanti Szerzödés irányába történő elkötelezettség egyértelmüen felértékelte az addig periférikus/félperiférikus régió gazdasági jelentöségét. A régió Budapestet és agglomerációját követöen a külföldi múködötöke legfontosabb célpontjává vált, melyben az országos arányokhoz képest még dominánsabb szerepet vállaltak a valamikor hagyományosnak mondható német (különösen délnémet), valamint osztrák befektetések és vállalkozások. A dinamikus gazdasági szerkezetváltás és a megjelenö külföldi töke hatására megindult a határ menti gazdasági kapcsolatok helyreállítása, megújítása, valamint új kapcsolatok kiépítése és bővítése (új export-import kapcsolatok, együitmüködések stb.). A Nyugat-dunántúli régió gazdaságában egyre erősebbé váltak a határmentiségböl fakadó elönyök és lehetöségek, illetve különösen az EU-csatlakozás közeledtével a hátrányok és veszélyek hatása a térség gazdasági szereplöinek mindennapi tevékenységére.

Az Európai Unióhoz való csatlakozással az áruk és szolgáltatások többségének területén teljes mértékben megvalósult az egységes belső piacra jellemzö szabad áramlás elve, míg a tőkepiac és a munkaerő vonatkozásában a mobilitást még átmeneti korlátozások akadályozzák. Ugyanakkor folyamatosan érezhető a határon átnyúló kapcsolatok, valamint a verseny intenzitásának erősödése. Az átmeneti korlátozásoknak az elkövetkezendő 4-5 évben történő teljes lebontásával szinte mindenkiben felmerül a kérdés, hogy az egységes belső piac tényleges megvalósulása miként hat a régió gazdaságára. Hogyan befolyásolja a régióban müködő vállalkozások tevéknységét, versenyképességét egy lehetséges integrált határrégió kialakulása, és egy, a szinergiahatásokat kihasználni képes határgazdaság?

\section{Vállalati felmérés általános paraméterei}

A Nyugat-dunántúli vállalkozásoknak a határ menti térségben való mủködése, a határmentiségnek a versenyképességükre gyakorolt hatása évek óta több kutatás fontos tárgyát képezte. Ezek megpróbálták feltárni a régióban mükődő cégek meglévő és jövöbeli határon átnyúló kapcsolatait, együttmủködési partnereit, legfontosabb belső és külső versenytényezöit, a magyar és az osztrák piac közötti alapvető különbségeket és hasonlóságokat, a határon átnyúló versenytársak pozícióit, valamint azok várható változását az EU-csatlakozást követően, az egységes belső piac kialakulásával (Grosz 2002, 2004b; Rhomberg-Bornett-Grosz-Pecher 2004; RhombergBornett-Gavac-Gittenberger-Kamptner-Mandl-Pecher-Radauer-Steiber 2004). A korábbi eredmények közül csak egy ábrát kiragadva jól látszik, hogy a régióban található vállalkozások fokozott figyelemmel kísérik a határ menti térségböl az integrált határrégió kialakulásáig vezető időszakot, hiszen az elkövetkezendő évtized gazdasági folyamatai jelentösen befolyásolják tevékenységüket (1. ábra). A korábban megkérdezett vállalkozások döntö többsége úgy vélte, hogy a jövöben 
növekedni fog az együttmüködési hajlandósága az osztrák, különösen a burgenlandi vállalkozások viszonylatában, ugyanakkor az osztrák szereplők által előidézett verseny élesedésében is hasonló növekedésre számítanak. A megkérdezett vállalkozások 2004-ben mind az együttmüködési hajlandóságot, mind pedig a verseny intezitását átlagosan 4-esre értékelték egy 1-töl 10-ig terjedö skálán. Ezzel szemben ez az érték 2010-re mindkét esetben megközelítette a 6-ot, 2015-re pedig meghaladta a 7-et (Grosz 2004a; Rhomberg-Gavac-Grosz 2004).

\section{1. ÁBRA}

A nyugat-dunántúli vállalkozások jövöbeli várakozásai ${ }^{*}$ (The Future Expectations of the West Transdanubian Enterprises)
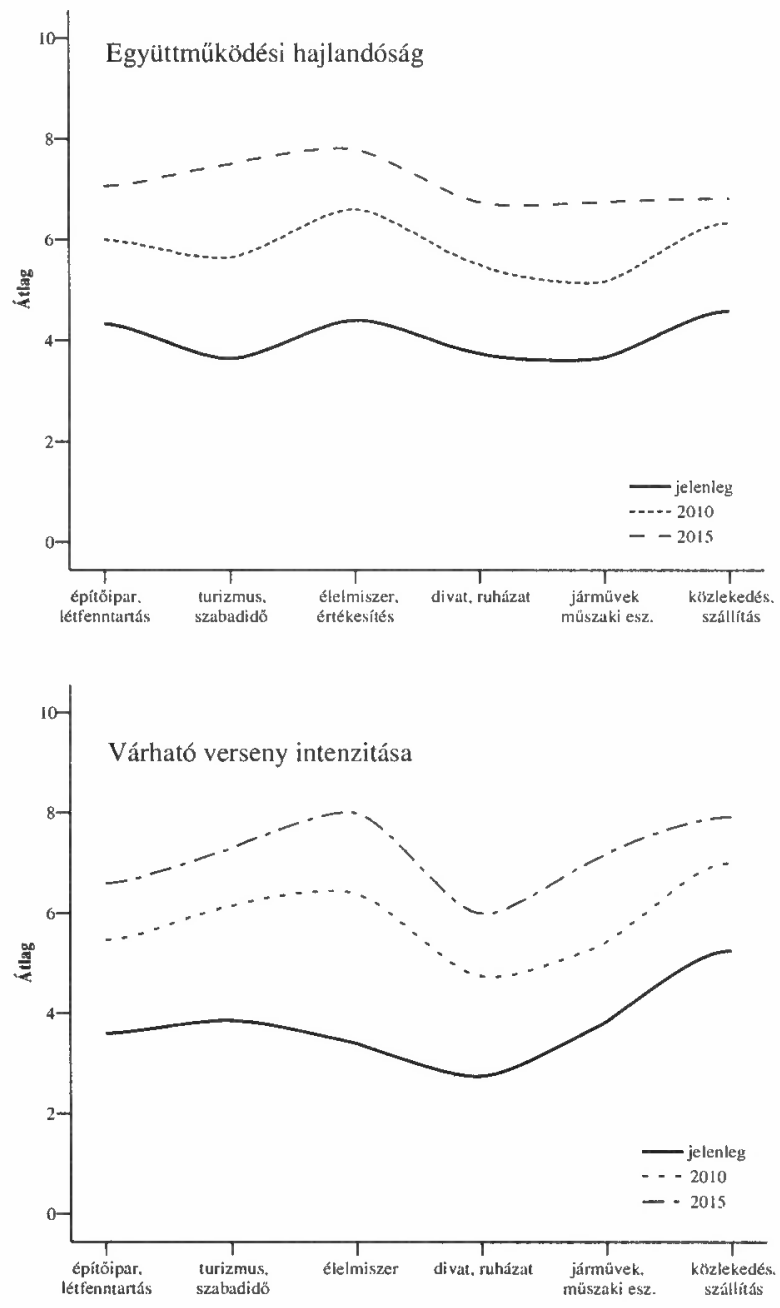

* Átlagos értékek 1-től 10-ig terjedỏ skálán, tevékenységi csoportonként

Forrás: A szerző saját szerkesztése. 
Grosz András: Vállalati együttmüködések a határ mentén magyar szemszögből.

Tér és Társadalom, 19. 2005. 2. 31-45. p.

A Nyugat-dunántúli régióban a kutatáshoz kapcsolódó vállalati felmérés összesen 300 vállalkozásra terjedt ki. A minta összeállítása során a megkeresett vállalkozások közül kihagytuk a 250 fö feletti nagyvállalatokat, ugyanis úgy véljük, hogy esetükben a telephelyválasztás során nem érzékelhetőek a határmentiségből fakadó elönyök oly mértékben, mint az egyéb telepítési tényezők (pl. infrastruktúra, elérhetöség, munkaerő, kedvezmények stb.), illetve általában a globális piacon való jelenlétük miatt müködésükre is sokkal kisebb hatással van a határ közelsége, mint a kisebb vállalkozásoknál. A megkérdezett 300 vállalkozásból összesen 250 vállalkozás alkotja a régió 250 fỏ alatti vállalkozásainak reprezentatív mintáját, melyen felül azonban további 50 olyan vállalkozást kerestünk meg, melyek valamilyen kapcsolatban állnak az osztrák piaccal. ${ }^{1}$ Ennek köszönhetöen pontosabb képet kaphatunk azon vállalati körrỏl, amely az ausztriai piaccal már valamilyen kapcsolatba került, illetve általuk alkotott véleményekröl, lehetséges jövőbeli változásokról.

A 250 vállalkozásnak mindössze $22 \%$-a rendelkezik osztrák piaci kapcsolatokkal, számuk 55. Így a teljes felmérés során a plusz 50 vállalkozással 105 ilyen cég található a mintában. Közülük 91 esetben tapasztalható export/import kapcsolat (megoszlásuk a 250/50 mintában 42/49), illetve 77 vállalkozásnál együttmüködési partner (34/43). A következökben, amikor az összes vállalkozás reprezentatív véleményére hivatkozunk, akkor azalatt a 250 eredeti vállalkozás válaszaiból származó eredményeket kell érteni, amennyiben pedig az osztrák piaccal kapcsolatban lévő vállalkozások véleményének ismertetésére kerül sor, az a 105, az osztrák piaccal valamilyen kapcsolatban lévő cég - a régió összes vállalkozására nézve - nem reprezentatív attitüdjét tükrözi.

A 250 vállalkozás közül 90 Györ-Moson-Sopron megyei, 82 Vas megyei, 78 pedig Zala megyében található. A megkérdezett vállalkozásoknak mindössze 4,5\%-ában található külföldi tulajdon (11 cég), 95,5\%-uk tisztán hazai tulajdonú, míg a kiegészítő felméréssel együtt a külföldi tulajdonú vállalkozások száma már eléri a 20-at (többségük a várakozásoknak megfelelỏen osztrák).

A nyugat-dunántúli kis- és középvállalkozások által folytatott gazdasági tevékenység székhely-, illetve telephelyválasztásában nem játszik igazán fontos szerepet a határhoz való közelség, és ezáltal az osztrák piaci kapcsolatokból fakadó előnyök és lehetőségek kiaknázása, ugyanakkor azt sem lehet mondani, hogy teljesen marginális tényezó lenne (2.ábra).

A megkérdezett cégeknek összesen $8 \%$-a értékelte fontosnak ezt az adottságot, míg a legfontosabb tényező egyértelmüen a lakóhelyhez való közelség volt, $62 \%$-os említési gyakorisággal. A lakóhelyhez való közelség mellett jelentős hatása van még a letelepedésre a meglévő - az ország keleti részéhez képest - fejlett infrastruktúrának (27\%), illetve a piac közelségének és a térségben rendelkezésre álló képzett munkaerőnek (17, ill. 16\%). A megkérdezett összes válallkozás közül mindössze kettő rendelkezett Ausztriában is telephellyel, illetve a jövöben is csak két cég tervezi az osztrák piacon az önálló telephely létrehozását. 


\section{2. ÁBRA}

A vállalkozások székhelyválasztását befolyásoló tényezök

(The Motivation Factors of Enterprises in Location Selection)

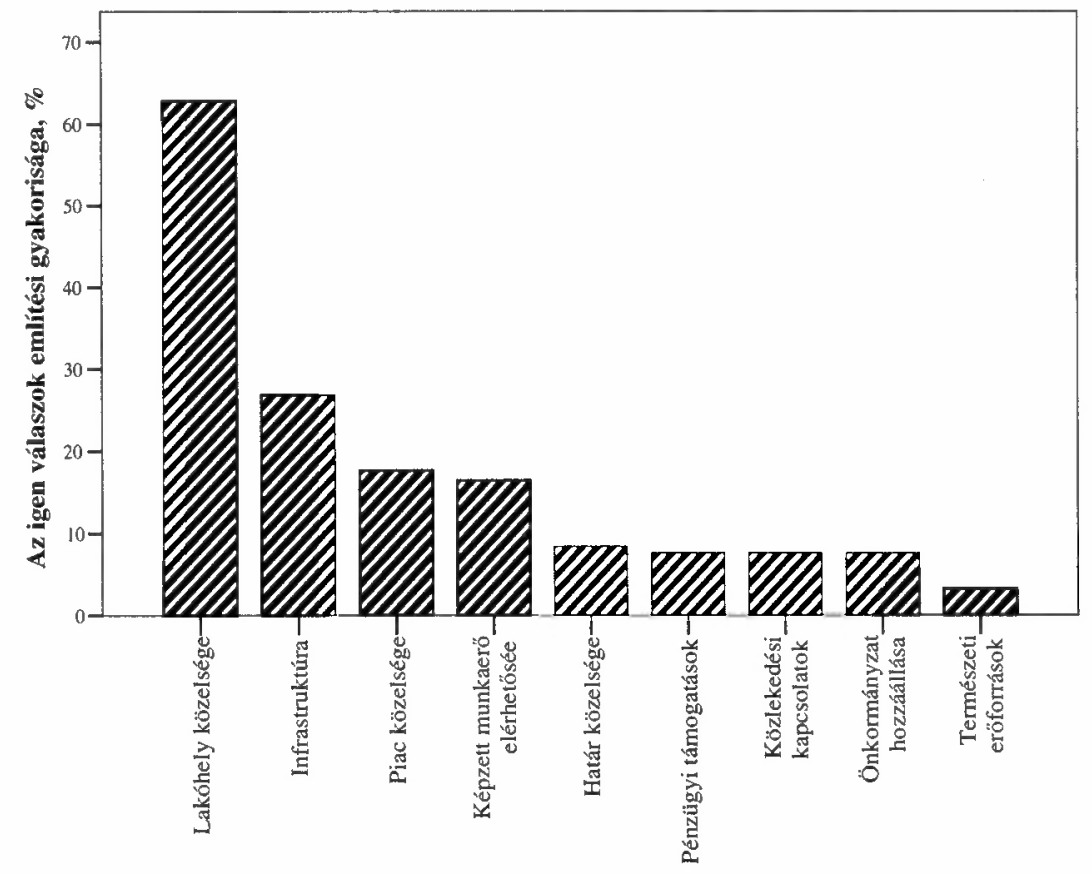

Forrás: A szerzỏ saját szerkesztése.

\section{Osztrák piaci kapcsolatok}

A felmérésben szereplö 250 vállalkozásnak mindössze 16,8\%-a rendelkezik Ausztriába irányuló, vagy Ausztriából származó export vagy import kapcsolatokkal. Ez az arány az előző években végzett hasonló kutatások eredményeihez képest nem igazán mutat jelentős változást. A vállalkozások között bár területileg is kimutatható kisebb különbség a külkereskedelmi aktivitást illetỏen (Vas megyében kb. kétszerese az ilyen tevékenységet végzők aránya, mint a régió másik két megyéjében, azonban ez nagy valószínűséggel Györ-Moson-Sopron és Zala megyék bizonyos részeinek az osztrák határtól való nagyobb távolságával is magyarázható), egyértelmủen meghatározó viszont a külföldi tulajdonos szerepe. Ha mind a 300 válaszadót vizsgáljuk, kiderül, hogy a külföldi tulajdonban lévő cégek több mint fele folytat ausztriai külkereskedelmi tevékenységet, míg ez az arány a tisztán hazai cégek esetében mindössze $15 \%$. Érthetően még magasabb az ausztriai tulajdonban lévô vállalkozásoknál, ahol meghaladja a 85\%-ot. 
Az osztrák piaccal export/import tevékenységet folytató 91 vállalkozás többsége (61\%-a) ugyanazokkal a termékekkel versenyez az osztrák piacon, mint a hazain. Ugyanakkor többségben vannak az ausztriai piacon a magyar piachoz többnyire hasonló, vagy teljesen azonos termékválasztékkal megjelenő cégek, arányuk $40 \%$. A vállalkozások további $35 \%$-a csak az itthoninál szúkebb választékkal van jelen az osztrák piacon, míg a cégek egynegyede a hazainál bövebb termékválasztékot kínál. Vajon indokolt-e az osztrák és a magyar piacok megkülönböztetése, az azokra történő eltérő termékdifferenciálás, illetve más-más termékválaszték?

Az összes vállalkozás véleménye alapján két olyan tényezőben tapasztalható a legmarkánsabb különbség a két piac között, amely esetében a bövebb termékválaszték, vagy akár a jobb minőségü termékek és szolgáltatások sem segíthetnek. Ugyanis ez a két tényező a korrupció, valamint a bürokrácia nagysága. A válaszadók több mint $70 \%$-a szerint mindkettő egyértelmủen a magyar piacra jellemző csak. Ezzel szemben inkább az ausztriai piac jut a vállalkozások eszébe, ha a fizetési fegyelemröl, környezeti tudatosságról, a környezet állapotának megóvására vonatkozó jogszabályokról, eröteljes marketingtevékenységröl van szó (valamennyi esetében 50\% feletti az osztrák piac említése).

Az osztrák piacban lévő potenciális lehetőségekre hívja fel a figyelmet, hogy a megkérdezett vállalkozások szerint a piaci kereslet nagysága inkább az ausztriai piacra jellemző, illetve a kinti piacot kevésbé látják telítettnek (lehetséges természetesen, hogy ez utóbbi kérdésben az osztrák piacról nem rendelkeznek pontos információkkal). A többit a vállalkozások többsége mindkettőre jellemzőnek találta, azonban meg kell jegyezni, hogy az ausztriai említések ezen piaci sajátosságoknál is általában többszörösen meghaladják a magyart (pl. szállítási határidő, fegyelem, vevőkapcsolatok szerepe, minöségi szempontok stb.). Ha külön viszgáljuk az osztrák piaccal kapcsolatban lévő vállalkozások véleményét, nagyon hasonló eredményeket kapunk (3. ábra). Még inkább megerősítést nyernek azok a különbségek, amelyeket az előzőekben már említettünk (korrupció és bürokrácia nagysága a magyar oldalon, valamint a környezeti tudatosság és jogszabályok, marketing, igényesség, kereslet nagysága az osztrák oldalon).

A 250 megkérdezett nyugat-dunántúli kis- és középvállalkozás 13,6\%-a rendelkezett osztrák együttmüködési partnerrel (34 cég), ami valamivel alacsonyabb, mint az osztrák piaccal export vagy import kapcsolatban álló vállalkozások aránya. Ez, hasonlóan az előző csoporthoz egybecseng a korábbi kutatások tapasztalataival. Az együttmüködés intenzitása - azonos okokra visszavezetve - hasonló megyei különbségeket mutat, mint az export/import kapcsolatokkal rendelkező vállalkozások területi elhelyezkedése, hiszen a két csoport között igen jelentős átfedés is tapasztalható. Míg Vas megyében a cégek 23\%-a jelzett együttmúködési kapcsolatot, Györ-Moson-Sopron megyében már csak 12\%, a Zala megyei vállalkozások közül pedig már csak minden huszadik. 
Grosz András: Vállalati együttmüködések a határ mentén magyar szemszögből.

Tér és Társadalom, 19. 2005. 2. 31-45. p.

\section{3. ÁBRA}

A magyar és az osztrák piac közötti hasonlóságok és különbségek* (Similarities and Differencies between the Hungarian and the Austrian Markets)
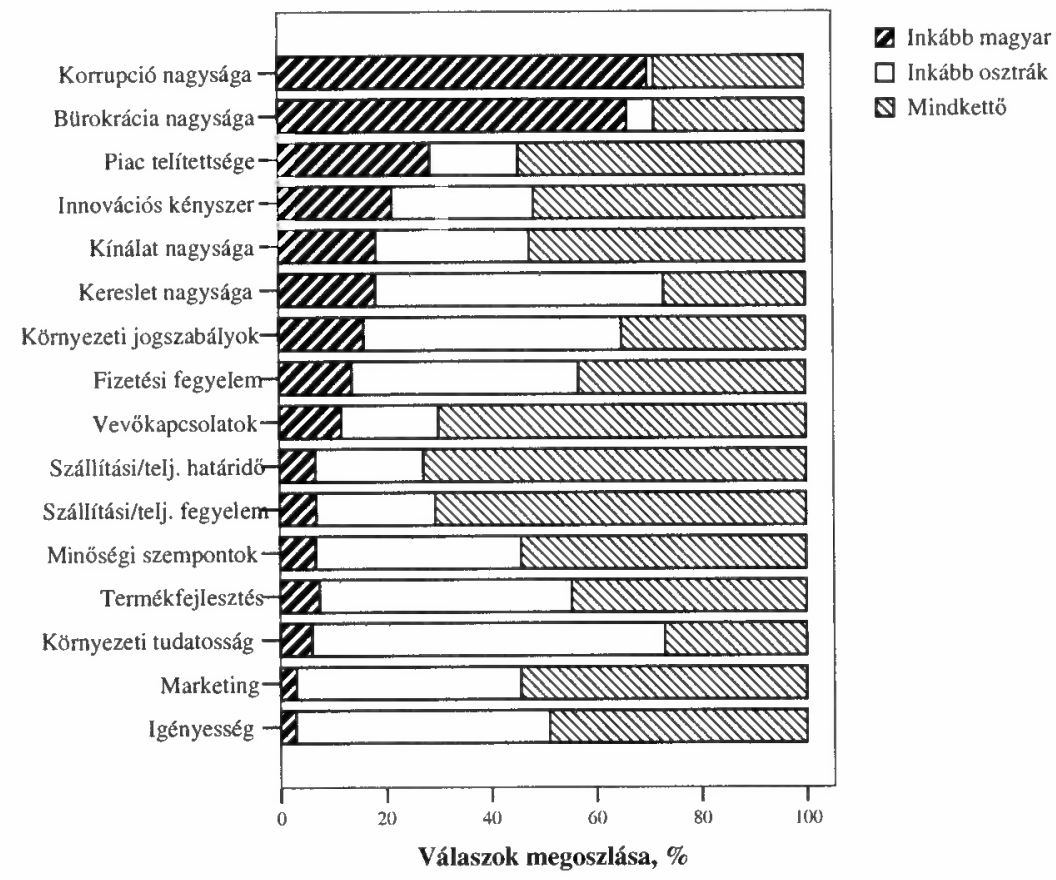

* Az osztrák piaccal kapesolatban lévö vállalkozások véleménye alapján, $\mathrm{N}=105$

Forrás: A szerző saját szerkesztése.

Jóval magasabb ugyanakkor azon nyugat-dunántúli cégek aránya, amelyek osztrák versenytárssal rendelkeznek, számuk eléri a 74-et, ami már majd 30\%-a a megkérdezett 250 vállalkozásnak. A versenytárssal rendelkező válallkozások területi elhelyezkedése szinte teljesen hasonló az együttmüködési kapcsolatokkal rendelkezökéhez, megintcsak Vas megye felülreprezentált, esetében a vállalkozásoknak kétszer akkora hányadát érinti, mint a másik két megye esetében, amelyek területének jelentős része távol esik az osztrák határtól.

\section{A határmentiség megítélése}

A konkrét osztrák piaci kapcsolatok (export/import tevékenység, együttmüködések) és versenytársak mellett kíváncsiak voltunk arra is, hogy a Nyugat-Dunántúlon mủködő kis- és középvállalkozások hogyan ítélik meg a határmentiséget, a nyugati határhoz való közelséget. Vajon milyen elönyök és hátrányok származnak az osztrák határhoz való közelségből? 
Grosz András: Vállalati együttmüködések a határ mentén magyar szemszögböl.

Tér és Társadalom, 19. 2005. 2. 31-45. p.

A határmentiségböl fakadó két legfontosabb, vagy legalábbis leggyakrabban említett elöny egyértelmủen a nagyobb vásárlóerő és a nagyobb kereslet érzékelhető jelenléte, melyeket közel 25\%-os gyakorisággal említettek a cégek, míg a többi elöny esetében ez az arány már 15\% alatti volt (4. ábra). Érdekes - ugyanakkor a székhelyválasztásnál már látott prioritásokat ismerve kevésbé meglepő -, hogy a vállalkozások döntö többségének az osztrák határhoz való közelség semmiféle elönyt nem jelent tevékenysége szempontjából.

\section{4. ÁBRA}

A határ közelségéböl fakadó elönyök

(Advantages Derived from the Closness of the Border)

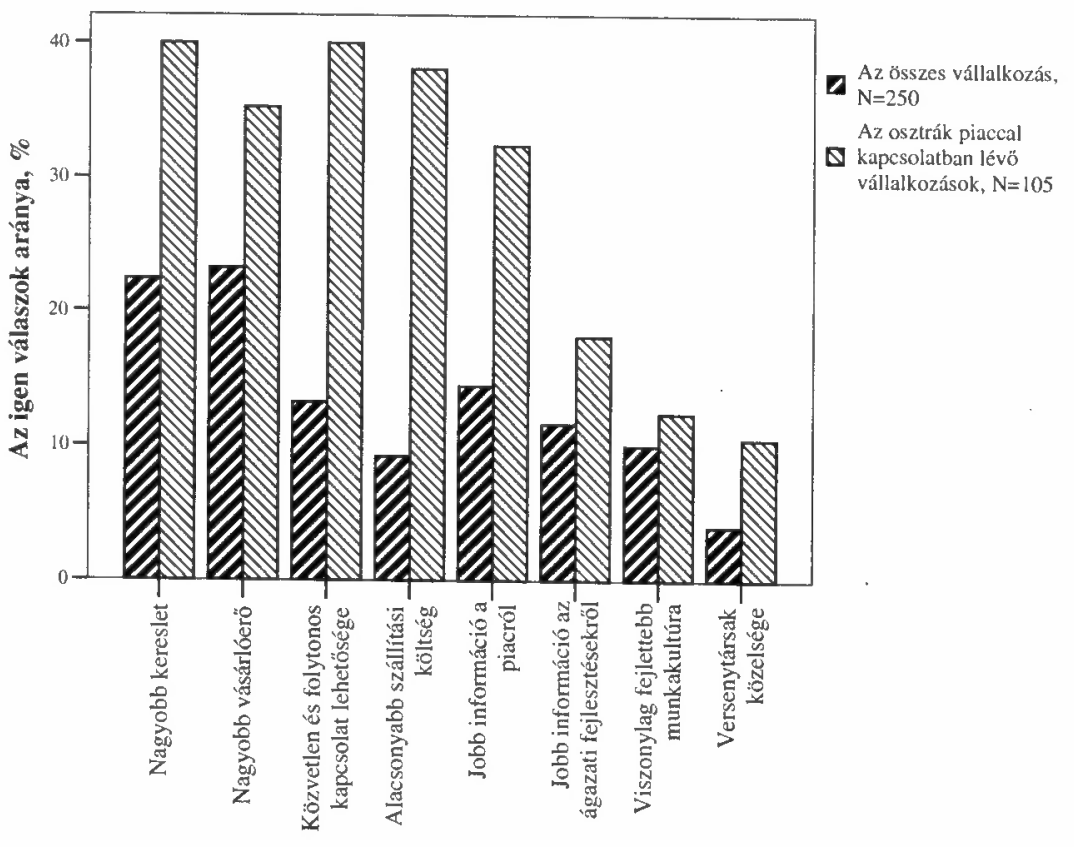

Forrás: A szerző saját szerkesztése.

$\mathrm{Az}$ osztrák piaccal már valamilyen szinten kapcsolatba került vállalkozások ugyanakkor már sokkal markánsabb véleményt voltak képesek adni, hiszen ők azok, akik a tényleges előnyöket mindennapi tevékenységük során realizálják (4. ábra). Egyfelöl a 105 vizsgált vállalkozás jóval nagyobb arányban nevezte meg az egyes elönyöket, másfelöl a nagyobb vásárlóerő és kereslet mellett egyértelmủen megjelentek más pozitív hatások is. Így ugyancsak közel 40\%-os említési gyakorisággal szerepel az osztrák határ közelsége által biztosított lehetőség a közvetlen és folyamatos kapcsolattartásra a külföldi (ausztriai) partnerekkel, illetve a viszonylag kis földrajzi távolságból fakadó alacsonyabb szállítási költségek. Ugyancsak jóval magasabb a piaci információkhoz, illetve az ágazatra jellemző fejlesztésekre vonatkozó információkhoz való gyorsabb és hatékonyabb hozzáférés. Érdekes, és már a 
fejlettebb tevékenységek jelenlétére utalhat, hogy az osztrák piaccal kapcsolatban lévő cégek $10 \%$-a számára a versenytársak közelsége is előnyként került értékelésre. Egyedül a viszonylag fejlett munkakultúrát nem értékelték pozitívabban, hiszen azt az osztrák piaccal kapcsolatban nem lévő vállalkozások jobban érzékelik.

A határ közelségéből származó negatív hatások közül a megkérdezett vállalkozások a versenytársak közelségét említették a leggyakrabban (5. ábra). Azonban még a versenytársak közelségét is mindössze 18\%-uk tekinti hátránynak, annak ellenére, hogy a cégek $30 \%$-a rendelkezik osztrák versenytárssal. Az összes többi jellemzö hátrányként való említése nem érte el a $15 \%$-ot sem. Az osztrák piaccal kapcsolatban lévő cégek - hasonlóan a határmentiségből származó elönyökhöz - már pontosabb és határozottabb véleménnyel rendelkeznek a hátrányokról is. Körükben már 25\%-ot ért el a versenytársak közelségének, illetve a Magyarországon belül relatív magas munkabérköltségének az említése, de a cégek egyötöde számára a nagyobb minőségi elvárások is a határhoz való közelség negatív számlájára írandók.

\section{5. ÁBRA}

A határ közelségéböl fakadó hátrányok

(Disadvantages Derived from the Closness of the Border)

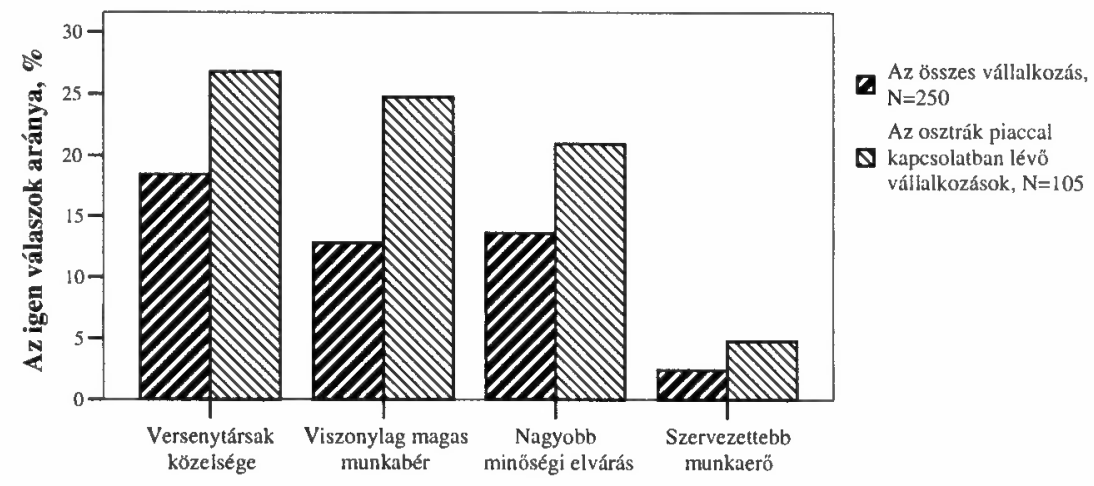

Forrás: A szerző saját szerkesztése.

\section{A versenyképesség alakulása a határ mentén}

A rendszerváltást követő nyitott gazdaságpolitika eredményeként egyre jobban érezhető a hazai vállalkozások számára is a globalizáció hatása, valamint a vállalatok versenyképességére ható tényezök fontossága. Az ország külpiaci orientációja, különösképpen a nyugati (EU) piacok felé fordulás mind az export, mind az import kapcsolatokban megmutatkozik. Az egyre szabadabbá vált áru- és szolgáltatásáramlás ugyanakkor a külföldi vállalkozásokkal szembeni verseny jelentős mértékü növekedéséhez vezetett, mely az EU-csatlakozással és az egységes belső piaccal várhatóan még meghatározóbbá válik a jövőben. A külföldi versenytársak szerepe a földrajzi távolság/közelség miatt különösen erős a nyugati határ menti vállalkozások körében, amelyeknek a hazai piacon kell versenyezniük az osztrák konkurenciával, 
Grosz András: Vállalati együttmüködések a határ mentén magyar szemszögből.

Tér és Társadalom, 19. 2005. 2. 31-45. $p$.

ugyanakkor az ország többi vállalkozásához képest viszonylag elönyösebb helyzetben vannak az ausztriai piacon való megmérettetést tekintve. Ezért rendkívül fontos megvizsgálni, hogy vajon az osztrák versenytársakkal összehasonlítva, melyek azok a legfontosabb külső és belső tényezök, amelyek a nyugat-dunántúli vállalkozások számára inkább előnyként jelentkeznek, illetve, melyek azok, amelyek versenyképességüket rontják.

A nyugat-dunántúli kis- és középvállalkozások számára a vállalatok tevékenységétöl függő, ún. belső vállalati tényezők közü] a termékek/szolgáltatások ára, valamint minősége, illetve az üzleti kapcsolatokra jellemző megbízhatóság került megemlítésre a teljes megkérdezetti körben, ugyanakkor még ezen válaszok gyakorisága sem érte el a 40\%-ot. Ugyanakkor mind a 15 belső tényezőt legalább a cégek 20\%-a értékelte inkább előnyként. Az árat, mint belső tényezőt nem számítva valamennyi esetében a többség úgy foglalt állást, hogy azok nem mérvadóak az osztrák vállalkozásokkal szembeni versenyképességüket tekintve. Hátrányként elsösorban a megfelelő termékválaszték, az alkalmazott technológia, illetve a gépek, berendezések müszaki állapota, valamint az értékesítés során alakalmazott marketingtevékenység jelenik meg, körülbelül 25-30\%-os említéssel.

\section{6. ÁBRA}

A belsö tényezök hatása a versenyképességre

(The Effects of the Internal Factors to Competitiveness)

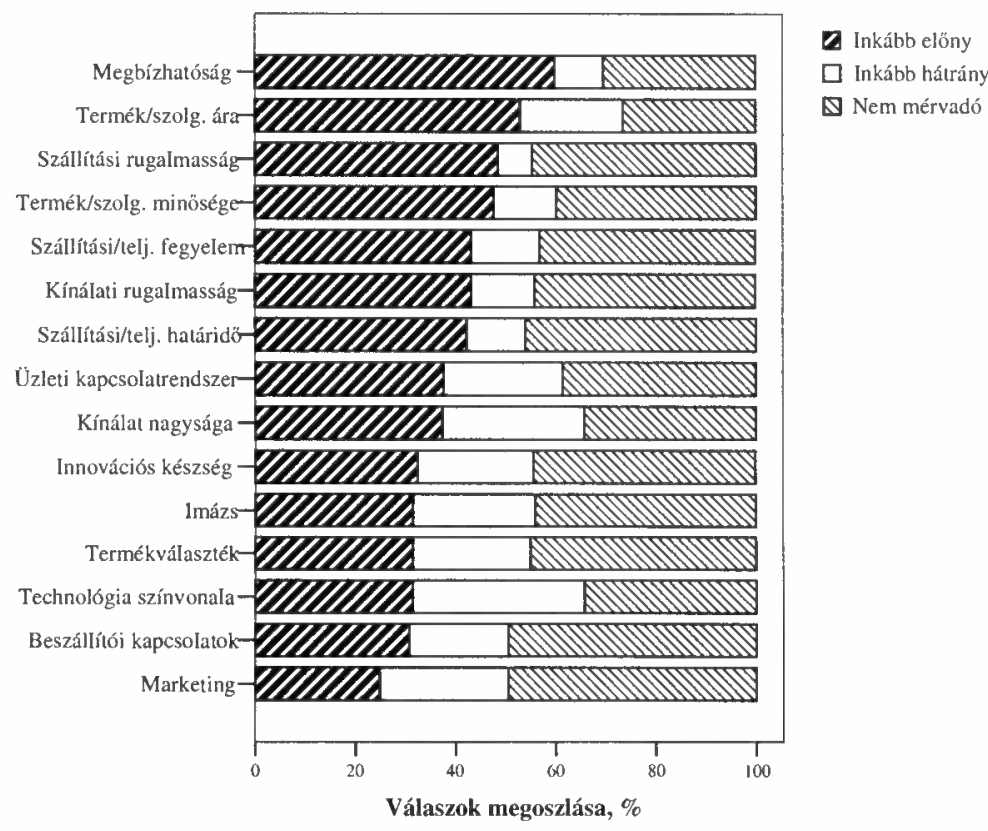

* Az osztrák piaccal kapcsolatban lévő vállalkozások véleménye alapján, $\mathrm{N}=105$

Forrás: A szerző saját szerkesztése. 
Az osztrák piaccal kapcsolatban lévő vállalkozások esetében, hasonlóan az eddigi eredményekhez, még pozitívabb kép alakulhat ki bennünk a hazai vállalkozások versenyképességéröl. Általában jellemző, hogy az összes vállalkozáshoz képest ez a csoport a tényezök többségét 15-20 százalékponttal magasabban említette elönyként (6. ábra). A válaszoló cégek közel $60 \%$-ával a megbízhatóság tünik a legfontosabb vállalatok által ismert versenyelőnynek, de az 50\%-os említési gyakoriságot meghaladja a termékek/szolgáltatások ára és minősége is, hasonlóan az előzỏekhez. Emellett ki kell még emelni a szállítással kapcsolatos tényezőket is, mint a szállítási rugalmasság, szállítási fegyelem, szállítási határidő. A versenyképességet tekintve legnagyobb probléma az osztrák piaccal kapcsolatba került vállalkozások szerint a hazai cégek marketingtevékenységében keresendö, de gyengén szerepelt a kínálat nagysága és a termékválaszték, valamint a technológiai színvonal is. Általában elmondható, hogy a vállalkozások belső tényezöi alapján a nyugat-dunántúli vállalkozások versenyképesnek látják saját magukat a hasonló tevékenységet végzỏ osztrák vállalatokkal összehasonlítva.

Egészen más a helyzet azonban, ha a vállalaton kívüli, a vállalkozások által közvetlenül nem befolyásolható, inkább a szủkebb gazdasági környezet, vagy a még tágabb külső nagyrendszerek oldaláról közelítjük meg a hazai cégek versenyképességét. Az összes vállalkozás véleménye alapján, mindössze a rendelkezésre álló munkaerö képzettsége tekinthető az ausztriai cégekkel szembeni versenyben inkább előnynek, mint hátránynak. Azonban az elönyként értékelök is mindössze 35\%-ot tesznek ki. Közel hasonló arányban vannak a települési infrastruktúrát és a piaci kereslet nagyságát előnyként és hátrányként látók, míg a többi hét tényezỏ esetében egyértelmủen az azokra versenyképességüket hátrányosan érintő véleményen lévők adják a többséget. Különösen igaz ez az egész országra egységesen jellemzö adórendszerre, általános jogszabályi környezetre és a meglévő bürokráciára, a nagy rendszerek rugalmatlanságára, melyek hátrányként történő említési gyakorisága megközelíti a 60\%-ot.

A külső tényezők okozta versenyhátrány a hazai cégek számára még látványosabb az osztrák piaccal kapcsolatban lévő, és így az ausztriai vállalkozásokat és az ö versenyhelyzetüket talán még jobban ismerö vállalkozások kỏrében (7. ábra). Esetükben már egyértelmüen csak a rendelkezésre álló munkaerỏ képzettsége szerepel inkább versenyelönyként az osztrák konkurenciával szemben, azonban a teljes vállalati mintához képest e tényezỏt is kevesebben tartják pozitívumnak. Ugyanakkor még magasabb a többi külső tényezőt hátrányként értékelők aránya, mely az adórendszer, a bürokrácia és a jogszabályok esetében megkỏzelíti, illetve meg is haladja a 70\%-ot, ami rendkívül magasnak mondható. De nem sokkal kedvezöbb a helyzet a konkurencia jelenléte, a különbözö támogatási rendszerek tekintetében sem. Tehát míg a vállalaton belüli tényezöket alapvetően pozitívan vagy optimistán értékelik a nyugat-dunántúli kis- és középvállalkozások, addig a vállalatok versenyképességére ható külső környezet jellemzőit egyértelmüen negatívan szemlélik, a külsỏ tényezőket tekintve a versenyelőnyök elsorvadnak, egy nagyfokú elégedetlenség tapsztalható. 


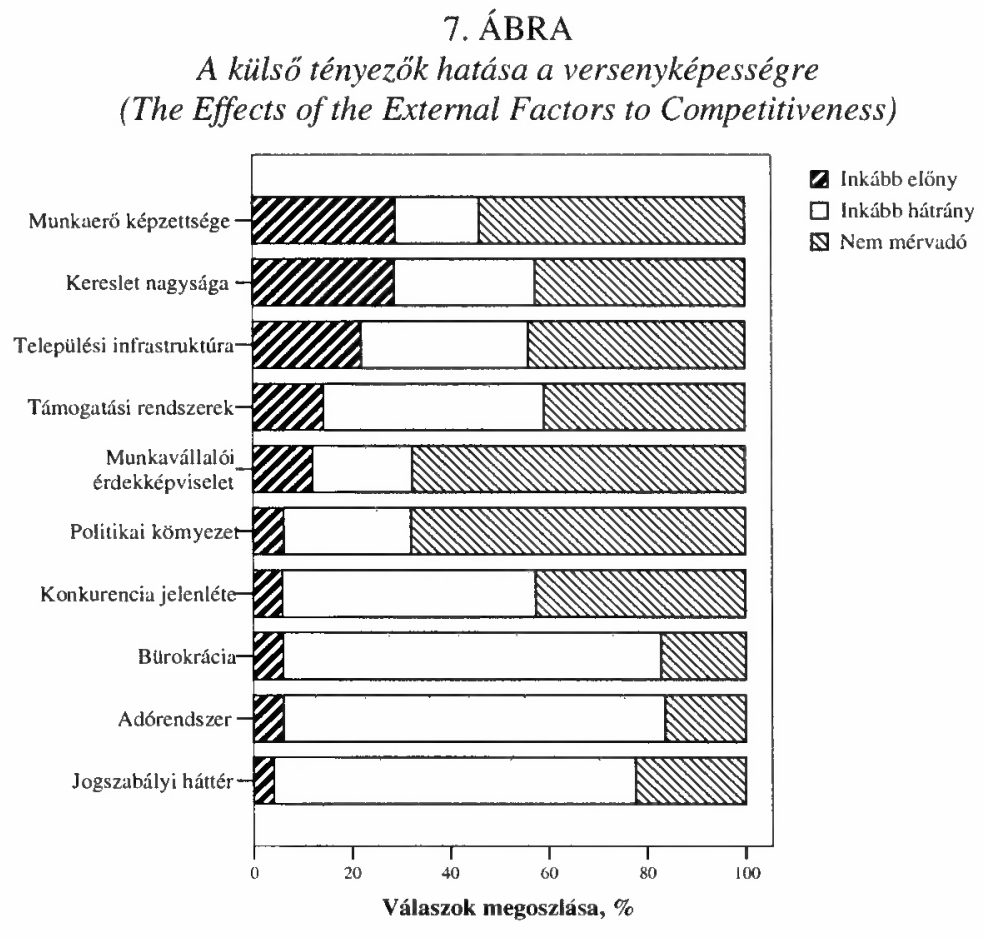

* Az osztrák piaccal kapcsolatban lévö vállalkozások véleménye alapján, N=105

Forrás: A szerzỏ saját szerkesztése.

\section{Az európai uniós csatlakozás}

Végül néhány gondolat erejéig szeretnénk kitérni az EU-csatlakozás elmúlt egy évben érzékelhető hatására ( 8 . ábra). A megkérdezett vállalkozások döntő többsége (62\%) véleménye szerint a csatlakozás hatására a vállalkozás életében semmilyen különösebb változás nem történt. A változásokat tapasztaló cégek $27 \%$-a, illetve az összes megkérdezett vállalkozás mindössze egytizede számolt be arról, hogy a válla]kozás üzleti lehetőségei - vélhetöen a nagyobb konkurencia, élesebb verseny hatására - romlottak, míg a változást érzékelők közel fele (az összes vállalkozás 18\%-a) üzleti, piaci lehetöségeinek javulása miatt a csatlakozás pozitiv hatásait érzékelte. Az összes vállalkozás körülbelül egytizede üzletpolitikájának új alapokra való helyezésére kényszerült, ami ugyanakkor közép vagy hosszabb távon egyáltalán nem biztos, hogy negatív a vállalkozás fejlódésére. Az osztrák piaccal kapcsolatban lévő vállalkozások esetében jóval kisebb - a vállalkozásoknak alig több mint egyharmada - azok aránya, akik szerint az EU-csatlakozás hatása a cég müködésében nem érzékelhető, míg a vállalkozások több mint $40 \%$-a szerint egyértelmúen pozitív hatással volt üzleti lehetőségeikre az egységes belső piachoz való kapcsolódás. Mindössze a cégek 7\%-a szerint rontotta a csatlakozás a meglévő üzleti lehetőségeiket. 


\section{8. ÁBRA \\ Az EU-csatlakozás hatása \\ (The Effects of EU Accession)}
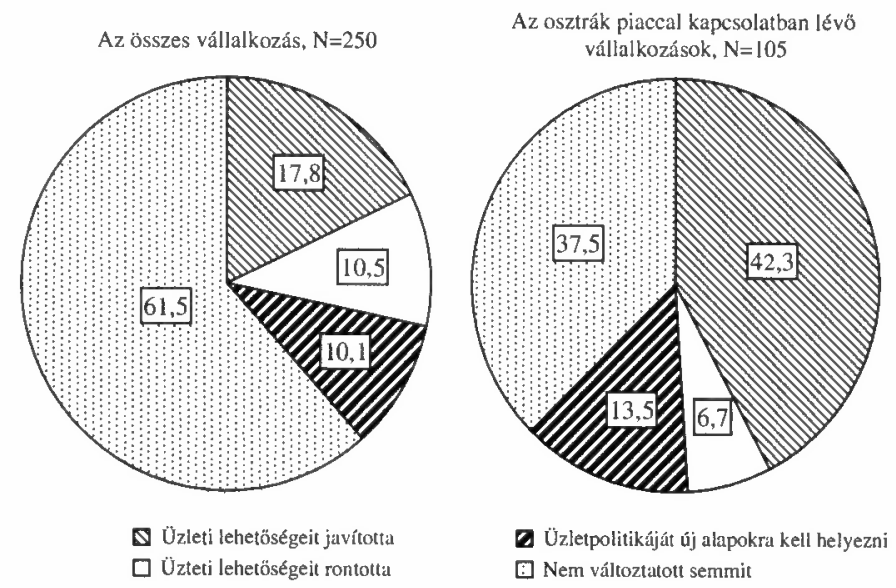

Forrás: A szerzỏ saját szerkesztése.

\section{Összefoglalás}

A Nyugat-dunántúli régióban müködő vállalkozások a nyugati határhoz való földrajzi közelségük miatt sokkal jobban érzik mindennapi müködésük során a határmentiségből fakadó előnyöket (pl, nagyobb potenciális piaci kereslet, könynyebb exportlehetőségek, külföldi kapcsolatok kialakításának és fenntartásának a lehetösége, információhoz való hozzáférés). Ugyanakkor az ország többi térségében múködỏ vállalatokhoz képest, szintén az osztrák határhoz való közelség nemcsak elönyökkel, de hátrányokkal is jár, melyek következtében a nyugat-dunántúli vállalkozások egy részének már sokkal előbb kellett, illetve kell megfelelnie az EU egységes piacára jellemző versenyfeltételeknek. Hiszen nem csak a hazai vállalkozásoknak jelent lehetőséget az osztrák piac közelsége, de a magyar piac (különösen az osztrák határhoz közel lévő területek) is folyamatosan potenciális célterületévé válik az osztrák vállalkozásoknak. Így számolni kell a külföldi vállalkozások által támasztott nagyobb versennyel, a jobb életszínvonalból fakadó magasabb minőségi követelményekkel, vagy éppen költségoldalról, a nyugati országrészre jellemző magasabb munkabérekkel.

A határmentiségböl fakadó könnyebb kapcsolatépítésnek, illetve piachoz való közelségnek köszönhetỏen minden ötödik megkérdezett vállalkozás rendelkezik már valamilyen osztrák kapcsolattal (kereskedelmi partnerrel vagy bármilyen egyéb együttmüködési partnerrel). Az együttmüködési kapcsolatok száma és intenzitása, valamint az osztrák piac jelentősége a hazai vállalkozások számára a jövőben várhatóan folyamatosan bỏvül. A határ két oldalán elhelyezkedő piacok sajátosságai 
folyamatosan közelítik egymást, és a legtöbb tényezö tekintetében már megfigyelhetö a konvergencia. A legjelentősebb különbségek osztrák oldalról a környezeti értékek elötérbe helyezésében és az igényességben tapasztalhatók, míg a hazai piacot leginkább a korrupció versenyfeltételeket befolyásoló viszonylag nagy mértéke, valamint a rendszer túlbürokratizáltsága különbözteti meg.

A vállalkozások egyharmada már egyértelmüen érzékeli az osztrák versenytársak jelenlétét, konkurenciáját, és csakúgy, mint az együttmüködési kapcsolatok esetében, az elkövetkezendö 5-10 évben egyhangúlag a verseny intenzitásának várható fokozódására számítanak. Míg azonban a nyugat-dunántúli kis- és középvállalkozások saját belső versenyfeltételeiket alapvetően jónak találják - elsősorban a termékek/szolgáltatások árában, minőségében és a megbízhatóságban érzik versenyképesnek magukat az osztrák versenytársakkal szemben -, addig a külső tényezök tekintetében már egyértelmủen pesszimisták. Talán egyedül a munkaerő képzettsége jelent egyelöre külső előnyt - ami a szakképzési problémák miatt középtávon könnyen elolvadhat -, míg a hazai jogszabályi hátteret, adó-, illetve pénzügyi és egyéb támogatási rendszereket, vagy megint csak a túlzottan bürokratikus müködési mechanizmusokat már egyértelműen a versenyképességüket negatívan befolyásoló, és a vállalkozások által közvetlenül nem befolyásolható tényezöként látják. Ezen utóbbi problémák felhívják a figyelmet az egységes belső piac által támasztott versenyfeltételek átalakulására, hiszen azok a közeli jövőben már nemcsak a nyugatdunántúli vállalkozások számára lesznek egyre égetőbbek, hanem valamennyi magyar vállalkozást érinteni fogják.

\section{Jegyzet}

1 Az osztrák piaci kapcsolattal rendelkezés kritériuma a következö feltételek közül bármelyik teljesülése volt: (1) rendelkezik ausztriai export/import kapcsolattal, (2) rendelkezik ausztriai együttmükődési kapcsolattal, (3) rendelkezik osztrák tulajdonossal.

\section{Irodalom}

Grosz A. (2002) (szerk.) A magyar válallkozások várakozásai az EU-bövitéssel kapcsolatban. NYUTI Közleményei 140. MTA RKK Nyugat-magyarországi Tudományos Intézet, Györ.

Grosz A. (2004a) (szerk.) A kis-és középvállalkozások versenyképessége a Nyugat-dunántúli régióban. NYUTI Kőzleményei 163. MTA RKK Nyugat-magyarországi Tudományos Intézet, Györ.

Grosz A. (2004b) Együttmüködési lehetöségek a Jordes+ régióban a gazdaság és innovációs területén. MTA RKK Nyugat-magyarországi Tudományos Intézet, Györ.

Rhomberg, W.-Bornett, W.-Grosz, A.-Pecher, I. (2004) Betriebliche Strategien von KMU unter veränderten Bedingungen in Folge der EU-Erweiterung und Monitoring der regionalen, sektorspezifischen Marktentwicklung (STRATEEC). Teil 1: Untersuchung der branchen- und regionalbezogenen Auswirkungen der EU-Erweiterung auf den burgenländischen Handel und Straßenguitertransport. KMU Forschung Austria, Wien.

Rhomberg, W.-Bornett, W.-Gavac, K.-Gittenberger, E.-Kamptner, I.-Mandl, I.-Pecher, I.-Radauer, A.Steiber, N. (2004) Betriebliche Strategien von KMU unter veränderten Bedingungen in Folge der EUErweiterung und Monitoring der regionalen, sektorspezifischen Marktentwicklung (STRATEEC). Teil 2: EU-Erweiterung - Monitoring der Marktentwicklung im Burgenland und in Westungarn. KMU Forschung Austria, Wien.

Rhomberg, W.-Gavac, K.-Grosz, A. (2004) Zukunftsperspektiven Burgenland/Westungarn. KMU Forschung Austria, Wien. 


\title{
ENTERPRISE CO-OPERATION ALONG THE BORDER FROM HUNGARIAN POINT OF VIEW
}

\begin{abstract}
ANDRÁS GROSZ
The aim of this study is to demonstrate the most important effects of the border on the daily activities of the enterprises in the West Transdanubian region. The border play an important role in last 15 years development process in the West Transdanubian region, which region has one of the most dynamic economic growth in the last decade. The closeness to the border, and to western markets was especially important for foreign direct investments and adopting the western (Austrian) patterns of enterprises. The strengthening changes in the end of $80 \mathrm{~s}$ and first half of $90 \mathrm{~s}$ transform the long time isolated and partitioned border region fast to opened and rejoined border region. After the enlargement of the EU this transformation process expected to lead in the near future to the shape of an integrated border region with the free movement of products, services and production factors (capital and labour). One of the most important dimensions of the characteristics of this border region is economy, which embraces the cross-border activities, the foreign market relationships, the co-operation opportunities, the increasing competition of the enterprises operating in the West Transdanubian region and generally all economic advantages and disadvantages arise from the closeness of the border.
\end{abstract}

